\title{
Korjuuajan vaikutus nurmipalkokasvien kivennäispitoisuuteen
}

\author{
Mikko Tuori ${ }^{1, \text { nyk. 2) }}$, Kaisa Kuoppala ${ }^{2)}$, Pirjo Pursiainen ${ }^{1)}$ ja Maria Munck ${ }^{1)}$ \\ ${ }^{1)}$ Helsingin yliopisto, Kotieläintieteen laitos, 00014 Helsingin yliopisto \\ 2) MTT Kotieläintuotannon tutkimus, Eläinravitsemus, 31600 Jokioinen
}

\section{Tiivistelmä}

Nurmikasvien kasvu korjuuvaiheeseen sisältää monia muutoksia sekä kasvin koostumuksessa että sadon määrässä. Kasvin kehitysvaiheen edetessä eli kasvin vanhentuessa solunseinäaineen osuus lisääntyy ja vastaavasti solun sisältöaineen osuus vähenee. Tähän liittyy lehtien osuuden vähentyminen korren/varren kustannuksella ja sulavuuden ja rehun energia- ja valkuaisarvojen huonontuminen. Myös kasvin tuhkapitoisuus vähenee, koska pääkivennäisistä $(\mathrm{Ca}, \mathrm{P}, \mathrm{Mg}, \mathrm{K})$ valtaosa sijaitsee solun sisältöosassa. Muutokset ovat samansuuntaisia sekä nurmiheinä- että nurmipalkokasveilla, joskin nurmipalkokasveilla kalsiumista ja magnesiumista on suurempi osa solunseinässä verrattuna nurmiheinäkasveihin. Viimeksimainituilla kuitenkin kalsiumin ja magnesiumin kokonaismäärät ovat huomattavasti pienemmät kuin kaksisirkkaisilla palkokasveilla.

Kevätsadon (ensikasvu) puna-apilakasvustoista kerättiin näytteitä eri projektien yhteydessä: vuohenherneen korjuuaikakoe (1996), Legsil-projekti vv. 1998-2000 (puna-apila, sinimailanen, vuohenherne, keltamaite) sekä puna-apilan korjuuaikakoe (MTT:n hanke "Laadukkaan luomurehun taloudelliset mallit”, 2002-2003). Pääosa näytesarjoista oli HY:n Viikin opetus- ja tutkimustilalta (Helsinki). Puna-apila- ja vuohenhernenäytteitä otettiin myös HY:n Suitian opetus-ja koetilalta (Siuntio) sekä puna-apilanäytteitä MTT:n maatalousteknologian tutkimuksen tilalta (Vihti). Näytesarja muodostui viikon välein otetuista osanäytteistä, joiden lukumäärä vaihteli kahdesta yhdeksään. Näytesarjojen lukumäärä per kasvilaji vaihteli kahdesta viiteen. Näytteistä määritettiin kivennäisaineet $(\mathrm{Ca}, \mathrm{P}, \mathrm{Mg}, \mathrm{K}$, $\mathrm{Fe}, \mathrm{Cu}, \mathrm{Mn}, \mathrm{Zn}$ ) sekä rehuanalyysin mukainen koostumus. Lisäksi laskettiin jokaiselle näytteelle kasvupäivien lukumäärä (= päivät yli $5^{\circ} \mathrm{C}$ kasvun alkamisesta) sekä tehoisa lämpötilasumma. Näytteiden sulavuutta kuvaava D-arvo on määritetty in vitro -menetelmillä (2-vaiheinen pötsinestesulatus tai sellulaasiliukoisuus) tai käyttäen vastaavasta säilörehusta pässillä määritettyä sulavuutta. Kasvilajeittain laskettiin eri kivennäisille ( $\mathrm{Ca}, \mathrm{P}, \mathrm{Mg}$ ja $\mathrm{K}$ ) näytesarjoista regressioyhtälöt, joissa ao. kivennäisen pitoisuutta selitettiin erikseen kasvupäivillä, tehoisalla lämpösummalla ja D-arvolla. Mixed-mallissa koevuosi (sisältäen koepaikan vaihtelun) oli satunnaistekijänä.

Kivennäispitoisuudet vähenivät yleisesti kaikilla kasvilajeilla ensikasvun aikana vähenemisen hidastuessa näytekauden lopulla, jolloin kasvupäivien määrän toisen asteen vaikutus oli useissa tapauksissa merkitsevä. Fosforipitoisuus väheni kasvupäivää kohti eniten vuohenherneellä $(0,057 \mathrm{~g})$, kun vähenemä muilla kasvilajeilla oli 0,019-0,022 g. Tämä on myös osoitus vuohenherneen nopeammasta kasvurytmistä mm. apilaan verrattuna (Nykänen ym. 2005). Kaliumpitoisuuden muutos oli käyräviivainen, ja väheni nopeimmin sinimailasella ja vuohenherneellä. Kalsiumin vähentyminen suhteessa kasvin keskimääräiseen Ca-pitoisuuteen oli samaa luokkaa kuin vastaava fosforin vähentyminen. Poikkeuksena oli keltamaite, jonka Ca-pitoisuuteen kasvupäivällä ei ollut vaikutusta ja vuohenherne, jonka kalsiumpitoisuus hieman suureni. Tehoisan lämpösumman ja D-arvon selitysasteet kivennäisten muutoksiin olivat samaa luokkaa kuin kasvupäivien lukumäärän selitysasteet.

Tutkimusaineistossa puna-apilan kalsiumpitoisuus vaihteli 8-19 ja fosforipitoisuus 1,6-3,2 g/kg kuivaainetta. Vaihtelun merkitystä kuvaa $10 \mathrm{~kg}$ puna-apilan kuiva-ainetta syövän lypsylehmän kalsiumin saannin vaihtelu em. rehusta: saanti jää puoleen kalsiumin tarpeesta tai riittää tyydyttämään kokonaan 50 $\mathrm{kg}$ maitoa tuottavan lehmän tarpeen. Vastaava fosforipitoisuuden vaihtelu vastaa $15 \%$ fosforin kokonaistarpeesta.

Asiasanat: nurmipalkokasvit, korjuuaika, kasvuaste, kivennäisaineet 


\section{Johdanto}

Kasvien kivennäispitoisuuksiin vaikuttavat mm. kasvilaji, kasvin kehitysvaihe, maaperän $\mathrm{pH}$ ja kivennäisten määrä sekä näiden liukoisuus ja kemiallinen muoto sekä ilmastotekijät lämpötila ja kosteus. Nurmipalkokasvit sisältävät enemmän kalsiumia, magnesiumia, kaliumia, kuparia, sinkkiä ja kobolttia kuin nurmiheinäkasvit (Spears 1994). Kasvin kasvuasteen edetessä solunseinäaineen osuus suurenee ja vastaavasti solun sisältöaineen osuus vähenee. Tähän liittyy myös lehtien osuuden väheneminen varren kustannuksella. Nämä tekijät johtavat kasvin kivennäispitoisuuden vähentymiseen kasvin vanhetessa, koska kivennäisaineista fosfori, rikki ja kalium sijaitsevat solun sisältöaineessa, ja vain murto-osa solunseinäaineessa (Whitehead ym. 1985). Nurmipalkokasveilla kuitenkin kalsiumin kokonaismäärästä saattaa n. puolet sijaita solunseinä-aineessa (Whitehead ym. 1985), vaikka pitoisuus lehdissä on 2-4 kertainen verrattuna varren kalsiumpitoisuuteen (Minson 1990), joten kalsiumpitoisuuden vähentyminen kasvin vanhetessa ei ole niin huomattavaa kuin muutokset fosforin ja kaliumin pitoisuuksissa (Spears 1994). Kuitenkin märehtijöiden ruokinnassa nurmipalkokasveista tuleva suuri kalsiummäärä on huomioitava kivennäistäydennystä suunniteltaessa, mikä edellyttää rehujen kivennäispitoisuuksien tuntemista. Kasvin kehitysvaiheen vaikutuksen tunteminen auttaa kivennäispitoisuuksien arvioinnissa korjuuhetkellä. Nurmikasvien kasvun alkaminen ja kehitys keväällä talven jälkeen on lähes täysin riippuvainen tehollisesta kasvuajasta ja tehoisasta lämpötilasummasta (lämpötila yli $5{ }^{\circ} \mathrm{C}$ ) (Rinne ym. 2000), ja ensimmäisen nurmisadon sulavuus voidaan arvioida suurella tarkkuudella säätietojen perusteella. Koska kivennäisten pitoisuus on riippuvainen kasvin kehitysasteesta, kasvukauden säätiedoilla on yhteys myös kivennäiskoostumukseen. Nurmiheinien osalta tutkimustietoa säätietojen vaikutuksesta on julkaistu (Huokuna ja Hakkola 1984). Tässä tutkimuksessa esitetään tuloksia kasvuajan ja lämpötilasumman vaikutuksesta neljän nurmipalkokasvin (puna-apila, sinimailanen, vuohenherne ja keltamaite) kivennäispitoisuuksiin.

\section{Aineisto ja menetelmät}

Tutkimusaineisto käsittää eri nurmipalkokasvilajien ensikasvun aikaisia näytesarjoja, joita on kerätty muiden projektien yhteydessä eri vuosina. Näytevälinä oli viikko ja näytemäärä per sarja 2-10 (taulukko 1). Kasvustonäytteitä kerättiin alkaen v. 1996 vuohenherneen korjuuaikakokeesta, Legsil-projektista vv. 1998-2000 (puna-apila, sinimailanen, vuohenherne, keltamaite) sekä vv. 2002-2003 puna-apilan korjuuaikakokeesta (MTT:n hanke "Laadukkaan luomurehun taloudelliset mallit"). Pääosa näytesarjoista on HY:n Viikin opetus- ja tutkimustilalta (Helsinki). Puna-apila- ja vuohenhernenäytteitä on otettu lisäksi HY:n Suitian opetus-ja koetilalta (Siuntio) sekä puna-apilanäytteitä MTT:n maatalousteknologian tutkimuksen tilalta (Vihti). Näytesarjojen lukumäärä per kasvilaji vaihteli kahdesta viiteen. Näytteistä määritettiin kivennäisaineet $(\mathrm{Ca}, \mathrm{P}, \mathrm{Mg}, \mathrm{K}, \mathrm{Fe}, \mathrm{Cu}, \mathrm{Mn}, \mathrm{Zn})$ sekä rehuanalyysin mukaisia määrityksiä. Lisäksi laskettiin jokaiselle näytteelle kasvupäivien lukumäärä (= päivät kasvun alkamisesta, jolloin keskilämpötila on yli $5^{\circ} \mathrm{C}$ ) sekä tehoisa lämpötilasumma. Näytteiden sulavuutta kuvaava D-arvo on määritetty in vitro -menetelmillä (2-vaiheinen pötsinestesulatus tai sellulaasiliukoisuus) tai käyttäen vastaavasta säilörehusta pässillä määritettyä sulavuutta. Kasvilajeittain laskettiin eri kivennäisille $(\mathrm{Ca}$, $\mathrm{P}, \mathrm{Mg}$ ja K) näytesarjoista regressioyhtälöt, joissa ao. kivennäisen pitoisuutta selitettiin erikseen kasvupäivillä, tehoisalla lämpösummalla ja D-arvolla. Mixed-ohjelmalla lasketussa regressioyhtälön mallissa vakio ja kulmakerroin olivat sekä kiinteinä tekijöinä että eri vuosille satunnaistekijöinä (StPierre 2001). Kaikista näytesarjoista ei ollut sulavuusmäärityksiä. Puna-apilasta poistettiin poikkeavina arvoina 3 kalsiumarvoa ja yksi fosforiarvo. Vuohenherneestä poistettiin yksi kalsiumarvo.

\section{Tulokset ja tulosten tarkastelu}

Verrattaessa puna-apilan kivennäiskoostumusta (taulukko 2) rehutaulukoissa (MTT2004) ilmoitettuihin arvoihin (g/kg KA) kalsiumpitoisuus oli samaa luokkaa (rehutaulukoissa $15 \mathrm{~g}$ kukkivalla ja $16 \mathrm{~g}$ nupulla olevalla puna-apilalla). Fosfori- ja magnesiumpitoisuudet olivat pienempiä kuin rehutaulukossa (P 2,5-2,6 g ja Mg 3,5 g), ja kaliumpitoisuus oli suurempi (24-25 g ).

Kivennäispitoisuudet vähenivät kasvuajan edistyessä ja lämpösumman lisääntyessä. D-arvon vaikutus oli päinvastainen (taulukko 3). Vuohenherneen kalsiumpitoisuus oli poikkeus. Vuoden 1996 näytesarjan 
ensimmäisen näytteen (otettu 5.6.) kalsiumpitoisuus oli sarjan näytteistä pienin. Kaikissa muissa näytesarjoissa nuorimpien näytteiden kalsiumpitoisuus oli suurin. Vastaava ilmiö löytyy Whiteheadin ja Jonesin (1969) tutkimuksesta, jossa valko- ja puna-apilan kalsiumpitoisuus oli kasvukauden alussa nouseva, ja vasta sen jälkeen laskeva. Kasvuajan vaikutuksen suuruus kivennäisainepitoisuuksien muutokseen onkin riippuvainen siitä kasvuajankohdasta, mistä tarkastelu aloitetaan. Puna-apilan ja sinimailasen fosforipitoisuus per kuiva-ainekg väheni tässä tutkimuksessa hitaammin kuin Kivimäen (1959) tutkimuksessa: 0,019 vs. $0.021-0,025 \mathrm{~g}$ päivässä ja sinimailasella 0,022 vs $0.044 \mathrm{~g}$ päivässä. Vuohenherneen fosforin väheneminen oli nopeinta, ja se kuvastaa myös kasvin nopeata sulavuuden vähenemistä korjuukaudella (Nykänen ym. 2005). Fosforiin ja kaliumiin verrattuna kalsium- ja magnesiumpitoisuuksien yhteys kasvin kehitysvaiheeseen oli heikompi. Keltamaitteen kalsiumpitoisuutta ja vuohenherneen magnesiumpitoisuutta kasvin kasvuaika, tehoisa lämpösumma tai sulavuus eivät selittäneet lainkaan. Kaliumpitoisuuden muutos verrattuna muihin kivennäisiin oli käyräviivaisempaa siten, että pitoisuus pysyi kasvukauden alussa pidempään korkeana ennen kuin alkoi vähentyä. Raakavalkuaispitoisuus oli erittäin hyvä selittäjä kaikkien kasvilajien fosforipitoisuudelle $\left(\mathrm{R}^{2}\right.$ $=0,935-0,978)$. Kasvuston raakavalkuaispitoisuuden vähentyessä $1 \mathrm{~g}$ puna-apilan fosforipitoisuus väheni $0,010 \mathrm{~g}$ ja muiden kasvien $0,014 \mathrm{~g} / \mathrm{kg}$ kuiva-ainetta.

\section{Johtopäätökset}

Nurmipalkokasvien kalsiumpitoisuus on huomattavasti suurempi kuin nurmiheinäkasvien. Tämä sekä kivennäispitoisuuksien muutos kasvun aikana tulee huomioida ruokinnan kivennäistäydennyksessä.

\section{Kirjallisuus}

Huokuna, E. \& Hakkola, H. 1984. Koiranheinän ja timotein kasvu ja rehuarvon muutokset säilörehuasteella. Tiedote 8/84. Maatalouden tutkimuskeskus, Jokioinen. $54 \mathrm{p}$.

Kivimäe, A. 1959. Chemical composition and digestibility of some grassland crops with particular reference to changes caused by growth, season and diurnal variation. Acta Agriculturae Scandinavica Suppl. 5, 142 p.

MTT 2004. Rehutaulukot ja ruokintasuositukset [verkkojulkaisu]. Jokioinen: Maa- ja elintarviketalouden tutkimuskeskus. Julkaistu 30.6.2004. Saatavissa: http://www.agronet.fi/rehutaulukot/

Minson, D.J. 1990. Forage in ruminant nutrition. Academic Press, Inc. San Diego, USA.

Nykänen, A., Nissinen, O. \& Tuori, M. 2005. Effective temperature sum based harvesting prognoses for fodder legumes. Cost Action 852. Quality legume-based forage systems for contrasting environments. Workshop 10-12, November 2005, Grado, Italy. 1 p.

Rinne, M., Hellämäki, M., Nousiainen, J., Aura, E., Virkajärvi, P., Huhtanen, P. 2000. Nurmirehun korjuuajan valinta tarkemmaksi. In: Rinne, M. (toim.). Maataloustieteen päivät 2000. Kotieläintiede. Maaseutukeskusten Liiton julkaisuja 952: 122-125.

Spears, J.W. 1994. Minerals in forages. In: G. C. Fahey, G.C., jr. (ed.). Forage quality, evaluation, and utilization. National Conference on Forage Quality, Evaluation, and Utilization (1994: University of Nebraska), p. 281-317.

StPierre, N.R. 2001. Invited review: Integrating quantitative findings from multiple studies using mixed model methodology. Journal of Dairy Science 84: 741-755.

Whitehead, D.C., Goulden, K.M. \& Hartley, R.D. 1985. The distribution of nutrient elements in cell wall and other fractions of the herbage of some grasses and legumes. Journal of the Science of Food and Agriculture 36: 311 318

Whitehead, D.C. \& Jones, E.C. 1969. Nutrient elements in the herbage of white clover, red clover, lucerne and sainfoin. Journal of the Science of Food and Agriculture 20: 584-591.

Taulukko 1. Kasvustonäytteiden lukumäärä (vuosi, kasvupaikka)

\begin{tabular}{|c|c|c|c|c|c|c|c|}
\hline & 1996 & 1998 & 1999 & 2000 & 2002 & 2003 & Yht. \\
\hline Puna-apila & & $2(\mathrm{H})$ & $3(\mathrm{H})$ & $8(\mathrm{H})$ & $9(\mathrm{~S})$ & $7(\mathrm{~V})$ & 29 \\
\hline Sinimailanen & & $2(\mathrm{H})$ & $4(\mathrm{H})$ & & & & 6 \\
\hline Keltamaite & & & $4(\mathrm{H})$ & $8(\mathrm{H})$ & & & 12 \\
\hline Vuohenherne & $7(\mathrm{H})$ & $2(\mathrm{H})$ & $4(\mathrm{H})$ & & & $4(\mathrm{~S})$ & 17 \\
\hline
\end{tabular}

$\overline{\mathrm{H}}=$ Helsinki (HY/Viikin opetus- ja tutkimustila); $\mathrm{S}=$ Siuntio (HY $/$ Suitian opetus- ja tutkimustila); $\mathrm{V}=\mathrm{V}$ ihti (MTT/Maatalousteknologian tutkimus Vakola) 
Taulukko 2. Kasvustonäytteiden koostumus

\begin{tabular}{|c|c|c|c|c|c|c|}
\hline & $\mathrm{n}$ & Keskiarvo & Minimi & Maksimi & Mediaani & Keskihajonta \\
\hline $\begin{array}{l}\text { Puna-apila } \\
\text { Kasvuaika } \\
\text { Tehoisa lämpösumma } \\
\text { D-arvo (29 hav.) } \\
\text { TU } \\
\text { RV } \\
\text { RR } \\
\text { RK } \\
\text { NDF } \\
\text { ADF } \\
\text { ADL } \\
\text { Ca } \\
\text { P } \\
\text { Mg } \\
\text { K }\end{array}$ & 29 & $\begin{array}{c}59,0 \\
429 \\
66,4 \\
98,3 \\
182 \\
42,0 \\
208 \\
351 \\
211 \\
25,0 \\
14,7 \\
2,5 \\
2,8 \\
29,5\end{array}$ & $\begin{array}{c}24,0 \\
130 \\
55,5 \\
64,9 \\
123 \\
27,2 \\
105 \\
194 \\
101 \\
6,8 \\
7,9 \\
1,6 \\
1,9 \\
19,7\end{array}$ & $\begin{array}{c}93,0 \\
810 \\
76,3 \\
126,0 \\
263 \\
59,5 \\
342 \\
483 \\
351 \\
54,6 \\
19,4 \\
3,2 \\
3,8 \\
37,1\end{array}$ & $\begin{array}{c}59,0 \\
412 \\
67,3 \\
99,5 \\
181 \\
40,0 \\
198 \\
345 \\
204 \\
24,4 \\
15,1 \\
2,5 \\
2,9 \\
30,3\end{array}$ & $\begin{array}{c}18,98 \\
187,2 \\
5,06 \\
16,32 \\
39,9 \\
9,81 \\
69,4 \\
85,3 \\
72,9 \\
13,26 \\
2,66 \\
0,43 \\
0,49 \\
5,03\end{array}$ \\
\hline $\begin{array}{l}\text { Sinimailanen } \\
\text { Kasvuaika } \\
\text { Tehoisa lämpösumma } \\
\text { D-arvo (4 hav.) } \\
\text { TU } \\
\text { RV } \\
\text { RR } \\
\text { RK } \\
\text { NDF } \\
\text { ADF } \\
\text { ADL } \\
\text { Ca } \\
\text { P } \\
\text { Mg } \\
\text { K }\end{array}$ & 6 & $\begin{array}{c}63,0 \\
453 \\
62,9 \\
85,6 \\
169 \\
35,0 \\
296 \\
411 \\
295 \\
50,8 \\
15,5 \\
2,6 \\
1,9 \\
27,4\end{array}$ & $\begin{array}{c}47,0 \\
300 \\
61,0 \\
68,2 \\
147 \\
31,8 \\
247 \\
345 \\
239 \\
37,4 \\
13,7 \\
2,3 \\
1,6 \\
20,8\end{array}$ & $\begin{array}{c}80,0 \\
590 \\
64,9 \\
99,5 \\
191 \\
36,8 \\
331 \\
457 \\
345 \\
60,8 \\
19,2 \\
3,1 \\
2,2 \\
33,5\end{array}$ & $\begin{array}{c}64,5 \\
450 \\
62,8 \\
99,3 \\
170 \\
35,6 \\
299 \\
412 \\
297 \\
49,9 \\
15,0 \\
2,7 \\
1,8 \\
28,2\end{array}$ & $\begin{array}{c}11,66 \\
106,2 \\
1,60 \\
16,43 \\
16,1 \\
2,01 \\
28,0 \\
38,4 \\
35,9 \\
8,99 \\
1,95 \\
0,28 \\
0,22 \\
5,86\end{array}$ \\
\hline $\begin{array}{l}\text { Keltamaite } \\
\text { Kasvuaika } \\
\text { Tehoisa lämpösumma } \\
\text { D-arvo } \\
\text { TU } \\
\text { RV } \\
\text { RR } \\
\text { RK } \\
\text { NDF } \\
\text { ADF } \\
\text { ADL } \\
\text { Ca } \\
\text { P } \\
\text { Mg } \\
\text { K }\end{array}$ & 12 & $\begin{array}{c}63,5 \\
469 \\
62,4 \\
78,4 \\
158 \\
37,9 \\
255 \\
355 \\
257 \\
52,8 \\
11,8 \\
2,4 \\
2,2 \\
26,7\end{array}$ & $\begin{array}{c}26,0 \\
130 \\
53,4 \\
64,1 \\
129 \\
29,7 \\
131 \\
204 \\
131 \\
14,6 \\
10,1 \\
1,9 \\
1,7 \\
21,8\end{array}$ & $\begin{array}{c}93,0 \\
773 \\
69,4 \\
91,1 \\
211 \\
48,1 \\
371 \\
496 \\
377 \\
82,8 \\
15,1 \\
3,2 \\
2,9 \\
32,3\end{array}$ & $\begin{array}{c}63,0 \\
463 \\
63,6 \\
77,7 \\
151 \\
35,3 \\
241 \\
339 \\
245 \\
52,3 \\
11,5 \\
2,4 \\
2,3 \\
26,5\end{array}$ & $\begin{array}{c}18,12 \\
179,5 \\
5,03 \\
8,37 \\
24,4 \\
5,27 \\
73,4 \\
85,2 \\
72,8 \\
19,28 \\
1,33 \\
0,36 \\
0,37 \\
3,57\end{array}$ \\
\hline $\begin{array}{l}\text { Vuohenherne } \\
\text { Kasvuaika } \\
\text { Tehoisa lämpösumma } \\
\text { D-arvo (11 hav.) } \\
\text { TU } \\
\text { RV } \\
\text { RR } \\
\text { RK } \\
\text { NDF } \\
\text { ADF } \\
\text { ADL } \\
\text { Ca } \\
\text { P } \\
\text { Mg } \\
\text { K }\end{array}$ & 17 & $\begin{array}{c}53,9 \\
373 \\
62,2 \\
82,6 \\
223 \\
39,4 \\
274 \\
495 \\
290 \\
46,2 \\
9,0 \\
3,2 \\
2,1 \\
30,3\end{array}$ & $\begin{array}{c}31,0 \\
177 \\
54,2 \\
63,7 \\
151 \\
27,3 \\
112 \\
377 \\
132 \\
22,5 \\
6,9 \\
2,0 \\
1,7 \\
17,7\end{array}$ & $\begin{array}{c}76,0 \\
590 \\
74,1 \\
101,2 \\
374 \\
52,6 \\
359 \\
594 \\
389 \\
62,9 \\
12,0 \\
6,0 \\
2,7 \\
41,5\end{array}$ & $\begin{array}{c}54,0 \\
353 \\
63,2 \\
84,4 \\
216 \\
38,9 \\
286 \\
500 \\
302 \\
43,7 \\
9,0 \\
3,0 \\
2,0 \\
30,4\end{array}$ & $\begin{array}{c}13,04 \\
119,2 \\
5,78 \\
11,63 \\
55,4 \\
7,12 \\
63,4 \\
73,9 \\
65,1 \\
11,86 \\
1,71 \\
1,02 \\
0,23 \\
6,59\end{array}$ \\
\hline
\end{tabular}


SUOMEN MAATALOUSTIETEELLISEN SEURAN TIEDOTE NRO 21

Taulukko 3. Kasvuajan (pv), tehoisan lämpösumman $\left({ }^{\circ} \mathrm{C}\right)$, D-arvon $(\%)$ ja raakavalkuaispitoisuuden $(\mathrm{g} / \mathrm{kg} \mathrm{KA})$ vaikutus nurmipalkokasvustojen kivennäispitoisuuksiin

\begin{tabular}{|c|c|c|c|c|c|c|c|c|c|c|c|c|c|}
\hline & & $\mathrm{n}$ & Vakio A & $\mathrm{SE}$ & $\mathrm{P}$-arvo & Kerroin B 1 & $\mathrm{SE}$ & P-arvo & Kerroin B2 & $\mathrm{SE}$ & P-arvo & RMSE & Adj. $R^{2}$ \\
\hline \multicolumn{14}{|c|}{ Puna-apila } \\
\hline \multirow[t]{3}{*}{$\mathrm{Ca}$} & Kasvuaika, lin. & 26 & 21,07 & 1,235 & $<0,001$ & $-0,1121$ & 0,02413 & $<0,009$ & & & & 1,619 & 0,643 \\
\hline & Teh.lämpös., lin. & 26 & 19,65 & 0,723 & $<0,001$ & $-0,01152$ & 0,00154 & 0,002 & & & & 1,481 & 0,690 \\
\hline & D-arvo, lin. & 24 & $-12,40$ & 4,816 & 0,082 & 0,4099 & 0,06884 & 0,009 & & & & 1,254 & 0,748 \\
\hline \multirow[t]{4}{*}{$P$} & Kasvuaika, lin. & 28 & 3,68 & 0,359 & $<0,001$ & $-0,01889$ & 0,00429 & 0,012 & & & & 0,161 & 0,826 \\
\hline & Teh.lämpös,, lin. & 28 & 3,32 & 0,154 & $<0,001$ & $-0,00192$ & 0,00022 & 0,001 & & & & 0,179 & 0,793 \\
\hline & D-arvo, lin. & 26 & $-2,09$ & 1,002 & 0,129 & 0,06719 & 0,01351 & 0,016 & & & & 0,190 & 0,750 \\
\hline & $\mathrm{RV}$, lin. & 28 & 0,77 & 0,408 & 0,131 & 0,00978 & 0,00235 & 0,014 & & & & 0,079 & 0,955 \\
\hline \multirow[t]{3}{*}{$\mathrm{Mg}$} & Kasvuaika, lin. & 29 & 3,81 & 0,283 & $<0,001$ & $-0,01703$ & 0,00348 & 0,008 & & & & 0,292 & 0,543 \\
\hline & Teh.lämpös,, lin. & 29 & 3,54 & 0,261 & $<0,001$ & $-0,00175$ & 0,00047 & 0,020 & & & & 0,274 & 0,581 \\
\hline & D-arvo, lin. & 29 & $-0,76$ & 0,775 & 0,401 & 0,05398 & 0,01317 & 0,026 & & & & 0,281 & 0,475 \\
\hline \multirow[t]{8}{*}{ K } & Kasvuaika, lin. & 27 & 40,48 & 1,820 & $<0,001$ & $-0,2064$ & 0,03050 & 0,007 & & & & 2,678 & 0,681 \\
\hline & “,2. aste & 27 & 26,42 & 3,365 & 0,004 & 0,3575 & 0,1277 & 0,068 & $-0,00512$ & 0,001072 & 0,018 & 1,878 & 0,874 \\
\hline & Teh.lämpös,, lin. & 27 & 37,22 & 1,917 & $<0,001$ & $-0,02003$ & 0,00305 & 0,007 & & & & 2,365 & 0,725 \\
\hline & “, 2, aste & 27 & 32,50 & 2,196 & $<0,001$ & 0,00868 & 0,0114 & 0,502 & $-0,00004$ & 0,000012 & 0,056 & 2,044 & 0,846 \\
\hline & D-arvo, lin. & 27 & $-21,42$ & 7,177 & 0,058 & 0,7532 & 0,1042 & 0,006 & & & & 2,368 & 0,719 \\
\hline & ", 2.aste & 27 & $-118,48$ & 141,330 & 0,463 & 3,2979 & 85,6172 & 0,972 & $-0,01637$ & 85,6092 & 0,999 & 1,927 & 0,901 \\
\hline & $\mathrm{RV}$, lin. & 27 & 10,40 & 5,352 & 0,147 & 0,1019 & 0,0231 & 0,022 & & & & 2,436 & 0,743 \\
\hline & $\mathrm{RV}, 2$.aste & 27 & $-33,77$ & 7,655 & 0,022 & 0,6015 & 0,0808 & 0,005 & $-0,00136$ & 0,00021 & 0,008 & 1,515 & 0,880 \\
\hline \multicolumn{14}{|c|}{ Sinimailanen } \\
\hline \multirow[t]{4}{*}{$\mathrm{Ca}$} & Kasvuaika, lin. & 6 & 27,27 & 5,352 & 0,138 & $-0,1279$ & 0,07410 & 0,334 & & & & 1,214 & 0,567 \\
\hline & “, 2.aste & 6 & $-5,19$ & 7,438 & 0,612 & 0,8953 & 0,2263 & 0,058 & $-0,00851$ & 0,00183 & 0,043 & 0,398 & 0,972 \\
\hline & Teh.lämpös., lin. & 6 & 20,36 & 3,125 & 0,097 & $-0,01000$ & 0,00631 & 0,359 & & & & 1,352 & 0,294 \\
\hline & D-arvo, lin. & 4 & $-6,64$ & 22,518 & 0,796 & 0,34124 & 0,3582 & 0,441 & & & & 0,991 & $-0,032$ \\
\hline \multirow[t]{4}{*}{$P$} & Kasvuaika, lin. & 6 & 4,15 & 0,449 & 0,069 & $-0,02184$ & 0,00336 & 0,097 & & & & 0,052 & 0,960 \\
\hline & Teh.lämpös,, lin. & 6 & 3,46 & 0,270 & 0,049 & $-0,00163$ & 0,00032 & 0,121 & & & & 0,064 & 0,875 \\
\hline & D-arvo, lin. & 4 & $-3,58$ & 2,890 & 0,341 & 0,09686 & 0,04596 & 0,171 & & & & 0,127 & 0,534 \\
\hline & RV, lin. & 6 & 0,27 & 0,297 & 0,533 & 0,01421 & 0,00179 & 0,080 & & & & 0,046 & 0,961 \\
\hline
\end{tabular}


SUOMEN MAATALOUSTIETEELLISEN SEURAN TIEDOTE NRO 21

Taulukko 3, jatk. Kasvuajan (pv), tehoisan lämpösumman $\left({ }^{\circ} \mathrm{C}\right)$, D-arvon (\%) ja raakavalkuaispitoisuuden (g/kg KA) vaikutus nurmipalkokasvustojen kivennäispitoisuuksiin

\begin{tabular}{|c|c|c|c|c|c|c|c|c|c|c|c|c|c|}
\hline & & $\mathrm{n}$ & Vakio A & $\mathrm{SE}$ & P-arvo & Kerroin B 1 & $\mathrm{SE}$ & P-arvo & Kerroin B2 & SE & P-arvo & RMSE & Adj. $R^{2}$ \\
\hline \multicolumn{14}{|c|}{ Sinimailanen, jatkoa } \\
\hline \multirow{3}{*}{$\mathrm{Mg}$} & Kasvuaika, lin. & 6 & 2,97 & 0,587 & 0,142 & $-0,01650$ & 0,00806 & 0,289 & & & & 0,131 & 0,660 \\
\hline & Teh.lämpös, lin. & 6 & 2,48 & 0,327 & 0,083 & $-0,00132$ & 0,00066 & 0,296 & & & & 0,142 & 0,437 \\
\hline & D-arvo, lin. & 4 & $-1,55$ & 4,635 & 0,77 & 0,05294 & 0,07372 & 0,550 & & & & 0,204 & $-0,193$ \\
\hline \multirow[t]{5}{*}{$\mathrm{K}$} & Kasvuaika, lin. & 6 & 54,86 & 9,450 & 0,109 & $-0,4139$ & 0,1798 & 0,261 & & & & 2,449 & 0,786 \\
\hline & Teh.lämpös, lin. & 6 & 43,09 & 5,152 & 0,076 & $-0,03221$ & 0,01386 & 0,259 & & & & 2,316 & 0,665 \\
\hline & D-arvo, lin. & 4 & $-182,74$ & 77,644 & 0,143 & 3,30614 & 1,23508 & 0,116 & & & & 3,416 & 0,673 \\
\hline & $\mathrm{RV}$, lin. & 6 & $-28,38$ & 13,125 & 0,276 & 0,3303 & 0,0775 & 0,147 & & & & 2,785 & 0,775 \\
\hline & $\mathrm{RV}, 2$. aste & 6 & $-114,24$ & 180,370 & 0,641 & 1,3584 & 2,1545 & 0,642 & $-0,00305$ & 0,00640 & 0,716 & 3,100 & 0,721 \\
\hline \multicolumn{14}{|c|}{ Keltamaite } \\
\hline \multirow[t]{3}{*}{$\mathrm{Ca}$} & Kasvuaika, lin. & 12 & 12,50 & 1,514 & 0,077 & $-0,01108$ & 0,02328 & 0,717 & & & & 1,365 & $-0,074$ \\
\hline & Teh.lämpös., lin. & 12 & 11,94 & 1,135 & 0,060 & $-0,00016$ & 0,00245 & 0,958 & & & & 1,308 & $-0,099$ \\
\hline & D-arvo, lin. & 12 & 5,18 & 4,808 & 0,476 & 0,10580 & 0,07688 & 0,400 & & & & 1,284 & 0,075 \\
\hline \multirow[t]{4}{*}{$P$} & Kasvuaika, lin. & 12 & 3,63 & 0,078 & 0,014 & $-0,02066$ & 0,00473 & 0,143 & & & & 0,064 & 0,972 \\
\hline & Teh.lämpös, lin. & 12 & 3,13 & 0,229 & 0,047 & $-0,00163$ & 0,00015 & 0,057 & & & & 0,082 & 0,927 \\
\hline & D-arvo, lin. & 12 & $-1,14$ & 0,636 & 0,325 & 0,05579 & 0,00912 & 0,103 & & & & 0,139 & 0,799 \\
\hline & $\mathrm{RV}$, lin. & 12 & 0,17 & 0,181 & 0,514 & 0,01434 & 0,00114 & 0,050 & & & & 0,092 & 0,935 \\
\hline \multirow[t]{3}{*}{$\mathrm{Mg}$} & Kasvuaika, lin. & 12 & 2,94 & 0,277 & 0,060 & $-0,01037$ & 0,00508 & 0,290 & & & & 0,230 & 0,366 \\
\hline & Teh.lämpös, lin. & 12 & 2,67 & 0,196 & 0,047 & $-0,00081$ & 0,00061 & 0,409 & & & & 0,219 & 0,260 \\
\hline & D-arvo, lin. & 12 & $-1,20$ & 0,784 & 0,368 & 0,05538 & 0,01235 & 0,140 & & & & 0,193 & 0,666 \\
\hline \multirow[t]{5}{*}{ K } & Kasvuaika, lin. & 12 & 37,42 & 2,473 & 0,042 & $-0,1775$ & 0,0465 & 0,163 & & & & 2,049 & 0,704 \\
\hline & Teh.lämpös,, lin. & 12 & 34,19 & 1,876 & 0,035 & $-0,01654$ & 0,0032 & 0,122 & & & & 1,839 & 0,716 \\
\hline & D-arvo, lin. & 12 & $-12,57$ & 7,096 & 0,327 & 0,62116 & 0,1094 & 0,111 & & & & 1,683 & 0,771 \\
\hline & RV, lin. & 12 & 5,80 & 4,158 & 0,396 & 0,1338 & 0,0270 & 0,127 & & & & 1,889 & 0,743 \\
\hline & RV, 2.aste & 12 & $-36,63$ & 24,986 & 0,381 & 0,6455 & 0,3001 & 0,277 & $-0,00150$ & 0,00088 & 0,339 & 1,654 & 0,819 \\
\hline
\end{tabular}


SUOMEN MAATALOUSTIETEELLISEN SEURAN TIEDOTE NRO 21

Taulukko 3, jatk. Kasvuajan (pv), tehoisan lämpösumman $\left({ }^{\circ} \mathrm{C}\right)$, D-arvon $(\%)$ ja raakavalkuaispitoisuuden $(\mathrm{g} / \mathrm{kg} \mathrm{KA})$ vaikutus nurmipalkokasvustojen kivennäispitoisuuksiin

\begin{tabular}{|c|c|c|c|c|c|c|c|c|c|c|c|c|c|}
\hline & & $\mathrm{n}$ & Vakio A & SE & $\mathrm{P}$-arvo & Kerroin B 1 & SE & $\mathrm{P}$-arvo & Kerroin B2 & SE & P-arvo & RMSE & Adj. $R^{2}$ \\
\hline \multicolumn{14}{|c|}{ Vuohenherne } \\
\hline \multirow{6}{*}{\multicolumn{2}{|c|}{$\begin{array}{c}\text { Ca Kasvuaika, lin. } \\
\text { “, 2. aste } \\
\text { Teh.lämpös., lin. } \\
\text { “, 2. aste } \\
\text { D-arvo, lin. } \\
\text { “, 2. aste }\end{array}$}} & 16 & 3,96 & 1,260 & 0,052 & 0,08938 & 0,02348 & 0,032 & & & & 1,063 & 0,533 \\
\hline & & 16 & $-4,37$ & 3,970 & 0,351 & 0,4218 & 0,1532 & 0,071 & $-0,00314$ & 0,00143 & 0,159 & 0,860 & 0,655 \\
\hline & & 16 & 4,86 & 0,970 & 0,015 & 0,01058 & 0,00250 & 0,024 & & & & 1,119 & 0,547 \\
\hline & & 16 & 1,07 & 2,687 & 0,72 & 0,03243 & 0,01458 & 0,113 & $-0,00003$ & 0,000019 & 0,167 & 1,022 & 0,592 \\
\hline & & 10 & 24,20 & 4,582 & 0,119 & $-0,2390$ & 0,07051 & 0,012 & & & 1,072 & 0,574 & \\
\hline & & 10 & $-93,53$ & 39,974 & 0,257 & 3,4252 & 1,2432 & 0,222 & $-0,02834$ & 0,009626 & 0,208 & 0,885 & 0,751 \\
\hline \multirow[t]{7}{*}{$\mathrm{P}$} & Kasvuaika, lin. & 17 & 6,23 & 0,568 & 0,002 & $-0,05707$ & 0,00709 & 0,004 & & & & 0,294 & 0,864 \\
\hline & “, 2. aste & 17 & 9,87 & 1,045 & 0,003 & $-0,20041$ & 0,03744 & 0,013 & 0,00133 & 0,00035 & 0,061 & 0,202 & 0,936 \\
\hline & Teh.lämpös,, lin. & 17 & 5,33 & 0,486 & 0,002 & $-0,00601$ & 0,00086 & 0,006 & & & & 0,334 & 0,819 \\
\hline & ", 2. aste & 17 & 7,91 & 0,688 & 0,001 & $-0,02048$ & 0,00317 & 0,008 & 0,000019 & $4,04 * 10^{-6}$ & 0,044 & 0,201 & 0,935 \\
\hline & D-arvo, lin. & 11 & $-5,97$ & 1,491 & 0,156 & 0,1465 & 0,01729 & 0,075 & & & & 0,291 & 0,894 \\
\hline & ", 2.aste & 11 & 7,31 & 79,274 & 0,941 & $-0,3767$ & 90,2805 & 0,997 & 0,00492 & 90,240 & 1,000 & 0,257 & 0,969 \\
\hline & RV, lin. & 17 & $-0,04$ & 0,150 & 0,795 & 0,01427 & 0,00096 & $<0,001$ & & & & 0,118 & 0,978 \\
\hline \multirow[t]{3}{*}{$\mathrm{M}$} & g Kasvuaika, lin. & 17 & 2,19 & 0,2916 & 0,0049 & $-0,00117$ & 0,00599 & 0,858 & & & & 0,126 & $-0,050$ \\
\hline & Teh.lämpös,, lin. & 17 & 2,18 & 0,194 & 0,002 & $-0,00023$ & 0,00062 & 0,731 & & & & 0,128 & $-0,016$ \\
\hline & D-arvo, lin. & 11 & 1,71 & 0,649 & 0,231 & 0,00888 & 0,01026 & 0,546 & & & & 0,177 & $-0,017$ \\
\hline \multirow{7}{*}{ K } & Kasvuaika, lin. & 17 & 48,94 & 3,675 & $<0,001$ & $-0,3391$ & 0,02139 & $<0,001$ & & & & 0,877 & 0,962 \\
\hline & “, 2. aste & 17 & 42,28 & 5,269 & 0,004 & $-0,0759$ & 0,1481 & 0,644 & $-0,00245$ & 0,00137 & 0,215 & 0,794 & 0,969 \\
\hline & Teh.lämpös, lin. & 17 & 42,91 & 3,617 & 0,001 & $-0,0342$ & 0,00395 & 0,003 & & & & 0,783 & 0,964 \\
\hline & ", 2. aste & 17 & 39,57 & 4,631 & 0,003 & $-0,0161$ & 0,01427 & 0,343 & $-0,00002$ & 0,000018 & 0,222 & 0,693 & 0,972 \\
\hline & D-arvo, lin. & 11 & $-14,86$ & 12,824 & 0,453 & 0,6894 & 0,1694 & 0,153 & & & & 2,851 & 0,650 \\
\hline & RV, lin. & 17 & 13,79 & 3,516 & 0,030 & 0,0749 & 0,01248 & 0,009 & & & & 2,124 & 0,790 \\
\hline & $\mathrm{RV}, 2$.aste & 17 & $-13,03$ & 8,342 & 0,216 & 0,2947 & 0,06708 & 0,022 & $-0,00042$ & 0,000125 & 0,009 & 1,600 & 0,889 \\
\hline
\end{tabular}

